Cristiane Honora Millan

\title{
Influência de práticas de manejo e contexto da paisagem sobre a ocorrência de aves em plantio exótico de eucalipto
}

São Paulo

2013 


\section{Cristiane Honora Millan}

\section{Influência de práticas de manejo e contexto da paisagem sobre a ocorrência de aves em plantio exótico de eucalipto}

Dissertação apresentada ao Instituto de Biociências da Universidade de São Paulo, para a obtenção de Título de Mestre em Ciências, na Área de Ecologia.

Orientador: Prof. Dr. Luciano

Martins Verdade

São Paulo

2013 


\section{Ficha Catalográfica}

Millan, Cristiane Honora

Influência de práticas de manejo e contexto da paisagem sobre a ocorrência de aves em plantio exótico de eucalipto

42 páginas

Dissertação (Mestrado) - Instituto de Biociências da Universidade de São Paulo. Departamento de Ecologia.

1. Conservação de aves 2. Silvicultura de eucalipto 3. Práticas de manejo 4.

Modelagem hierárquica

I - Universidade de São Paulo. Instituto de Biociências. Departamento Ecologia.

\section{Comissão Julgadora:}




\section{Agradecimentos}

Agradeço primeiramente à minha família. À minha mãe, por estar sempre disposta a me dar uma dose de ânimo para continuar. Ao meu pai, por me apoiar e acreditar na minha opção de carreira. Ao meu irmão, por me ajudar a enxergar alguns desafios com muita objetividade e clareza.

Ao Prof. Luciano Martins Verdade por confiar tanto em mim e por me incentivar a conhecer o ambiente acadêmico de São Paulo.

Aos professores e colegas da LAGE, por me receberem no laboratório, pela amizade e pelo ambiente intelectual estimulante.

Ao Prof. Glauco Machado, por me ajudar no meu projeto e por se preocupar com a qualidade da minha formação como pesquisadora.

Ao Prof. Gonçalo Ferraz, por disponibilizar tempo para ler meu plano de pesquisa e me ajudar com as análises.

Por fim, agradeço aos meus amigos pelo carinho, apoio e diversão. Em especial à Moca, por estar sempre ao meu lado me incentivando a enxergar um lado positivo em absolutamente tudo; e à Gaya, por ser uma grande companheira em todos os momentos da vida. 


\section{SUMÁRIO}

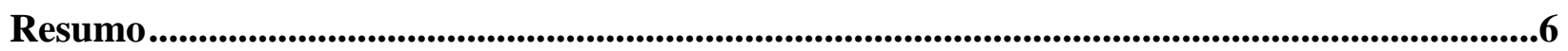

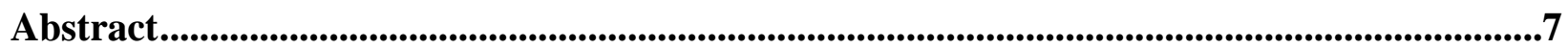

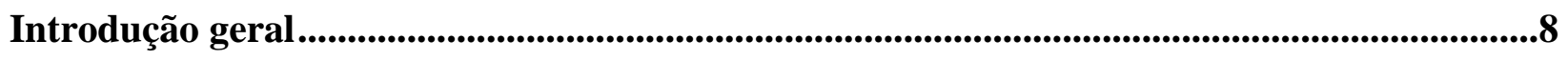

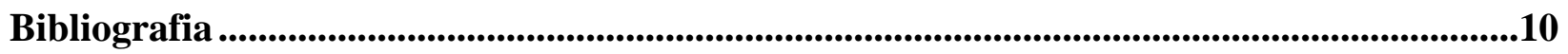

Influence of stand level management practices and landscape context on bird occupancy in exotic Eucalyptus plantations

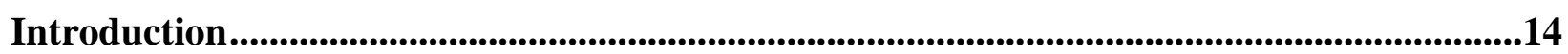

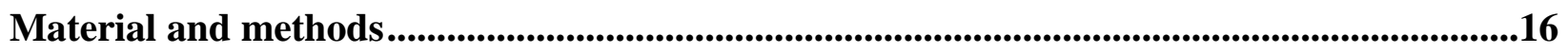

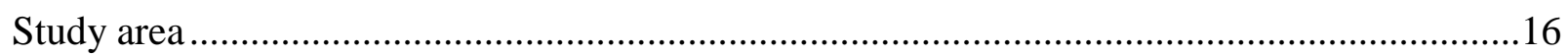

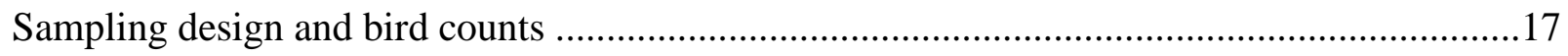

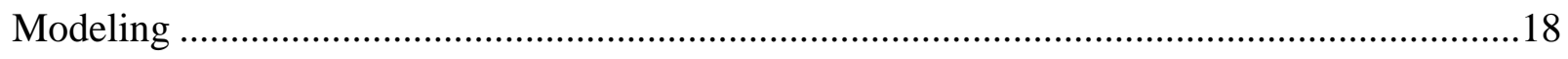

Site-specific traits: management and landscape covariates ...............................................20

Species-specific traits: sensitivity and foraging stratum covariates ...................................21

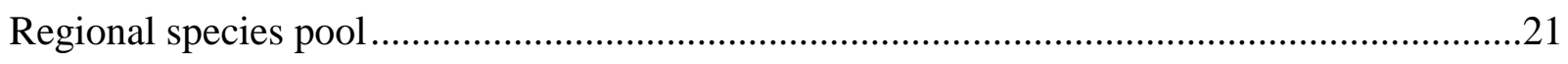

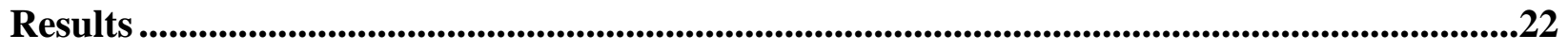

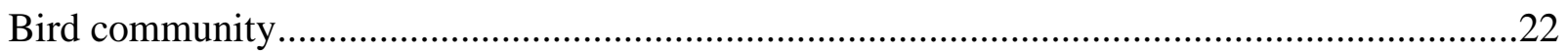

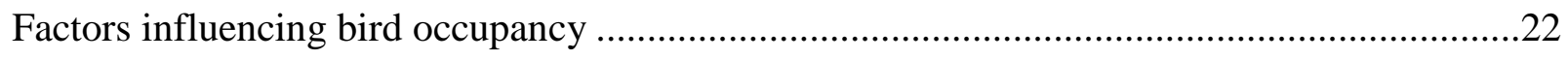

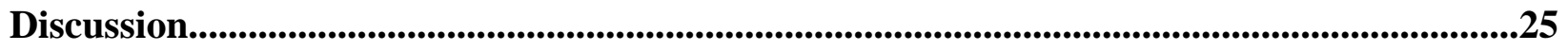

Influence of stand level management practices.........................................................26

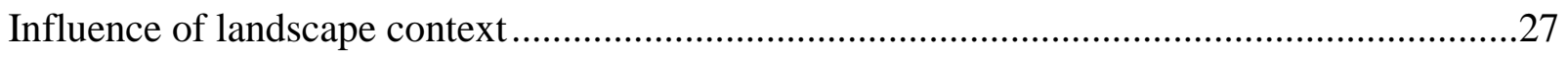

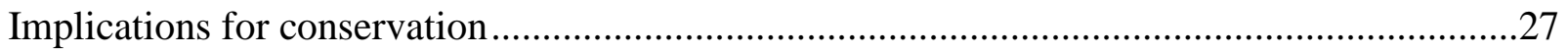

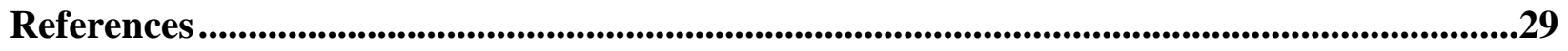

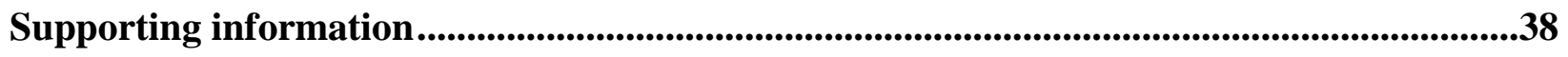

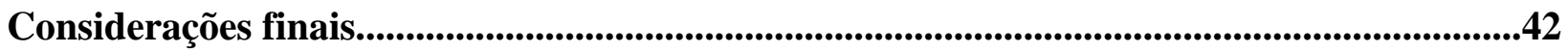




\section{RESUMO}

1. O manejo da vida silvestre em matrizes antropizadas, fora de reservas naturais, é importante para melhorar a eficácia de esforços conservacionistas que visam proteger e restaurar a biodiversidade. Desta forma, é fundamental entender as características da matriz que aumentam a adequabilidade do habitat para as espécies remanescentes e também avaliar as respostas das espécies à práticas de manejo alternativas.

2. Neste estudo utilizamos uma abordagem de modelagem hierárquica, que leva em conta o efeito de falhas de detectabilidade das espécies, para estimar o efeito de práticas de manejo adotadas dentro de talhões de plantios de Eucalyptus sobre a ocupação de aves. Nossos modelos incorporam características sítio-específicas, como tipo de prática de manejo e o contexto da paisagem em que se inserem cada unidade amostral. Também incorpora características espécie-específicas, em particular à sensibilidade das espécies aos distúrbios e estrato de forrageio.

3. O principal fator associado a diferenças na ocupação de aves dentro de nossa área de estudo é o tipo de pratica de manejo. A presença de árvores nativas dispersas e de subbosque em estágio inicial de sucessão dentro dos talhões está associada com um aumento na proporção de espécies do pool regional capaz de ocupar a matriz silvicultural. $\mathrm{O}$ contexto da paisagem teve um efeito relativamente menor sobre a ocupação de aves na área de estudo.

4. Síntese e Aplicação. A ocupação de aves está associada positivamente ao aumento da complexidade estrutural dentro dos talhões de eucalipto, as espécies respondem a retenção de árvores nativas dispersas e a presença de sub-bosque. Gerenciadores interessados em aumentar o valor conservacionista de plantios de Eucalyptus para as aves deveriam preservar as arvores maduras e adotar práticas que estimulem a regeneração do sub-bosque durante o preparo do local e rotação do plantio.

Palavras-chave: conservação de aves; modelagem hierárquica;; silvicultura; árvores isoladas; manejo de sub-bosque 


\begin{abstract}
1. Managing for wildlife in human-dominated matrices outside natural reserves has great importance to improve the efficacy of conservation efforts aiming to protect and restore biodiversity. As such, it is critical to understand which features of the matrix that enhance habitat suitability to the remaining species and also to evaluate species responses to alternative management practices.

2. We used hierarchical modeling to estimate the effect of stand level management practices adopted in Eucalyptus plantations on bird occupancy while accounting for species detection failure. Our models incorporate site- specific traits, such as management practice type and the landscape context of each sampling unit. It also incorporates species specific-traits, particularly species sensitivity to disturbance and species foraging stratum.

3. The major factor associated with differences in bird occupancy within our study site is the management practice type. Scattered native trees and early successional stage understory within mature stands was associated with an increase in the proportion of bird species from the regional pool that was able to occupy the silvicultural matrix. Landscape context had a relatively minor effect on bird occupancy in our study area.

4. Synthesis and applications. Bird occupancy is positively associated with increasing spatial heterogeneity within eucalyptus stands with species responding to the retention of native scattered trees and understory presence. Managers interested in improving the conservation value of Eucalyptus plantations to birds should preserve some existing trees and adopt practices that trigger understory regeneration during site preparation and stand rotation.
\end{abstract}

Keywords: bird conservation; hierarchical modeling; isolated trees; silviculture; understory management 


\section{Introdução geral}

O modelo de desenvolvimento econômico adotado no estado de São Paulo, principalmente a partir do século XIX, ocasionou profundas alterações em sua cobertura vegetal, que atualmente ocupa apenas $14 \%$ de sua área total original (Ribeiro et al., 2009). A paisagem original, formada predominantemente por Mata Atlântica e Cerrado, foi rapidamente transformada em um mosaico composto por matriz agropastoril e pequenos fragmentos florestais remanescentes (Dean, 1977, 1995). Diante da rápida degradação de habitats naturais por atividades humanas, foram criadas leis federais para a proteção do patrimônio natural brasileiro em áreas de domínio público. A criação das chamadas ‘unidades de conservação' (UCs) teve como objetivo central a conservação dos recursos naturais e da diversidade biológica de diferentes biomas do país (Brasil, 2000). Além das UCs federais, cada estado tem autonomia para a criação de outras áreas destinadas à conservação natural (Brasil, 2000). Em São Paulo, por exemplo, existem aproximadamente 4,7 milhões de hectares de UCs federais e estaduais, que se destinam à proteção de áreas de Mata Atlântica quanto de Cerrado (Secretaria do Meio Ambiente/SP, 2009). Adicionalmente, existem restrições sobre a exploração de florestas e outros tipos de vegetação nativa presentes em áreas particulares, descritas pelo Código Florestal Brasileiro (Brasil, 1965, 2012).

Na prática, as estratégias de conservação baseadas exclusivamente em reservas públicas têm um poder limitado de ação, pois se restringem às áreas relativamente pequenas e dispersas. Além disso, em função do crescimento da população humana e do consumo per capita, está previsto um aumento considerável no conflito de interesses entre a expansão agrícola e as áreas prioritárias para conservação (Dobrovolski et al., 2011). Um exemplo atual desse tipo de conflito é a recente pressão política feita pela "bancada ruralista" com o objetivo de "flexibilizar" o Código Florestal Brasileiro, o que pode resultar em um aumento do desmatamento e a provável perda da biodiversidade em vários remanescentes atualmente protegidos pela legislação (Metzger et al., 2010; Michalski et al., 2010).

Estudos empíricos demonstram que a sobrevivência e persistência a longo prazo de muitas espécies animais e vegetais estão associadas ao tipo de uso e manejo da terra em paisagens antropizadas (Daily, Ehrlich \& Sánchez-Azofeita, 2001; Fischer et al., 2005; Martin, et al., 2012). De acordo com o paradigma atual, paisagens alteradas deixaram de ser vistas como 
'não-habitat' e passaram a ser consideradas como potenciais áreas complementares para a conservação da biodiversidade (e.g., Meunier, Verheyden \& Jouventin, 2000; Ferraz et al., 2007; Verdade, et al., 2011). Contudo, estudos sobre a importância de paisagens antropizadas para a conservação de espécies devem incluir não apenas análises sobre a capacidade de persistência das espécies nos remanescentes de habitat nativo da paisagem, mas também uma análise da influência dos vários tipos de matriz em que se encontram estes remanescentes sobre padrões de riqueza e composição das comunidades (e.g., Dotta \& Verdade, 2011; Gheler-Costa et al.,2013) No estado de São Paulo, as áreas particulares abrigam a maior parte da vegetação nativa remanescente, cerca de 3,4 milhões de hectares dispersos principalmente em matriz agrícola (Kronka et al., 2005). Portanto, o conhecimento sobre as diferentes paisagens agrícolas do estado é fundamental para a elaboração de planos para a conservação da biodiversidade.

Atualmente, a silvicultura de eucalipto é o segundo principal cultivo em São Paulo, com um aumento de 26,9\% em área plantada (de 679.639 ha para 862.505 ha) na última década (Pino, 2009). Essa expansão ocorreu a partir de 1960, principalmente sobre áreas ocupadas por pecuária extensiva de baixa produtividade, como a centro-sul e leste do estado (Viana et al., 2007). A mudança no tipo de uso da terra transformou drasticamente a paisagem agrícola regional, que passou a ser composta principalmente por fragmentos florestais, fragmentos de pasto em regeneração e matriz de plantio de eucalipto. Algumas consequiências da transformação de grandes porções da paisagem em silvicultura comercial sobre comunidades animais já foram elucidados. Muitos desses estudos enfocam os efeitos da perda e fragmentação de habitats, comparando a diversidade presente nas florestas comerciais com a diversidade presente em ambientes florestais nativos (e.g., Estades \& Temple, 1999; Renjifo, 2001; Barlow, et al., 2007; Zurita \& Bellocq, 2010). Alguns autores sugerem possíveis medidas de manejo com o intuito de aumentar a biodiversidade de tais áreas alteradas, porém poucos estudos de fato testaram a influência destas medidas sobre a fauna em diferentes ecossistemas (Hartley, 2002).

Para as aves de sistemas florestais tropicais, os plantios de eucalipto são ambientes relativamente pobres e incapazes de abrigar uma grande diversidade de espécies (Motta Jr, 1990; Marsden, Whiffin \& Galetti, 2001; Zurita et al., 2006, Penteado, no prelo). Estudos sugerem que a ausência de sub-bosque nesses plantios seja a razão primária para a ausência de várias espécies de aves (Stallings, 1991; Marsden, Whiffin \& Galetti, 2001; Willis, 2003). A presença de subbosque aumentaria a complexidade estrutural do ambiente, pois aumentaria o número de estratos 
florestais do plantio. Como consequência da estratificação florestal, haveria uma maior disponibilidade de habitats e recursos para diferentes espécies (MacArthur \& MacArthur, 1961; MacArthur, 1964; Martin, 1988). Adicionalmente, a presença de árvores nativas remanescentes dentro dos plantios florestais pode implicar em um aumento local da diversidade de espécies (Recher \& Serventy, 1991; Fischer \& Lindenmayer, 2002; Manning, Fischer \& Lindenmayer, 2006). Essas árvores nativas têm o potencial de atrair novas espécies de aves, pois podem prover recursos que um plantio comercial de árvores, constantemente manejado e com ciclo de curta duração, não oferece, tais como frutos, néctar e cavidades para nidificação. Bibby (1989), por exemplo, demonstrou que em plantios exóticos de Pinus na Inglaterra a presença de uma única espécie de árvore nativa remanescente atraiu 11 espécies de aves especialistas para o local.

Esta dissertação é composta por um capítulo, redigido em formato de artigo, no qual foi avaliada a influência de duas técnicas de manejo sobre a diversidade de aves em um sistema de silvicultura de eucalipto: o manejo mínimo de sub-bosque e a retenção de árvores nativas nas áreas de plantios. O plano de pesquisa está inserido em um projeto mais amplo (Projeto Temático de Pesquisa Programa Biota/FAPESP, 06/60954-4) intitulado "Mudanças Socioambientais no Estado de São Paulo e Perspectivas para a Conservação”, que busca avaliar os processos econômicos, sociais e culturais que causaram as mudanças na paisagem do estado principalmente durante o século XX, bem como as consequências de tais modificações sobre a capacidade dos ecossistemas de produzir serviços ambientais indispensáveis à manutenção da vida.

\section{Bibliografia}

Barlow, J., Mestre, L.A.M., Gardner, T.A. \& Peres, C.A. (2007) The value of primary, secondary and plantation forests for Amazonian birds. Biological Conservation, 136, 212-231.

Bibby, C.J., Aston, N. \& Bellamy, P.E. (1989). Effects of broadleaved trees on birds of upland conifer plantations in North Wales. Biological Conservation, 49, 17-29.

Brasil (1965) Lei n. ${ }^{\circ}$ 4.771, de 15 de setembro de 1965. Institui o Novo Código Florestal. Diário Oficial da União, Brasília, DF, 16 de set. 1965.

Brasil (2000) Lei n. ${ }^{\circ}$ 9.985, de 18 de julho de 2000. Regulamenta o art. 225, $\S 1^{\text {o }}$, incisos I, II, III e VII da Constituição Federal, institui o Sistema Nacional de Unidades de Conservação 
da Natureza e dá outras providências. Diário Oficial da União, Brasília, DF, 19 de jul. 2000.

Brasil (2012) Lei n. ${ }^{\circ}$ 12.651, de 25 de maio de 2012. Dispõe sobre a proteção da vegetação nativa; altera as Leis n. ${ }^{0}$ 6.938, de 31 de agosto de 1981, 9.393, de 19 de dezembro de 1996, e 11.428, de 22 de dezembro de 2006; revoga as Leis n. ${ }^{\circ} 4.771$, de 15 de setembro de 1965, e 7.754, de 14 de abril de 1989, e a Medida Provisória n. ${ }^{\circ} 2.166-67$, de 24 de agosto de 2001; e dá outras providências. Diário Oficial da União, Brasília, DF, 28 de maio 2012.

Daily, G.C., Ehrlich, P.R \& Sánchez - Azofeita, A. (2001) Countryside biogeography: use of human-dominated habitats by the avifauna of southern Costa Rica. Ecological Applications, 11, 1-13.

Dean, W. (1977) Rio Claro: um sistema brasileiro de grande lavoura 1820-1920. Paz e Terra, Rio de Janeiro.

Dean, W. (1995) With broadax and firebrand: the destruction of the Brazilian Atlantic Forest. California University Press, Berkeley.

Dobrovolski, J.A., Diniz-Filho,, J.A.F., Loyola, R.D \& De Marco Jr. , P. (2011) Agricultural expansion and the fate of global conservation. Biodiversity and Conservation, 20, 24452459.

Dotta, G. \& Verdade, L.M. (2011) Medium to large-sized mammals in agricultural landscape of South-eastern Brazil. Mammalia, 75, 345-352.

Estades, C. N. \& Temple, S.A. (1999) Deciduous bird communities in a fragmented landscape dominated by exotic pine plantations. Ecological applications, 9, 573-585.

Ferraz, K.M.P.M.B., Ferraz, S.F.B., Moreira, J.R., Couto, H.T.Z. \& Verdade, L.M. (2007) Capybara (Hydrochoerus hydrochaeris) distribution in agroecosystems: a cross-scale habitat analysis. Journal of Biogeography, 34, 223-230.

Fischer, J. \& Lindenmeyer, D.B. (2002a) The conservation value of paddock trees for birds in a variegated landscape in southern New South Wales. Species compositions and site occupancy patterns. Biodiversity and Conservation, 11, 807-832.

Fischer, J., Fazey, I., Briese, R. \& Lindenmeyer, D.B. (2005) Making matrix matter: challenges in Australian grazing landscapes. Biodiversity and Conservation, 97, 71-88. 
Gheler-Costa, C., Sabino-Santos Jr., G., Amorim, L.S., Rosalino, L.M., Figueiredo, L.T M. \& Verdade, L.M. (2013) The effect of pre-harvest fire on the small mammal assemblage in sugarcane fields. Agriculture, Ecosystems and Environment, 171, 85-89.

Hartley, M.J. (2002) Rationale methods for conserving biodiversity in plantation forests. Forest Ecology and Management, 15, 81-95.

Kronka, F. J. N., Nalon, M.A., Matsukuma, C.K., Kanashiro, M.M, Ywane, M.S.S., Pavão, M., Durigan,G., Lima, L.M.P.R., Guillaumon, J.R., Baitello, J.B., Borgo, S.C., Manetti, L.A., Barradas, A.M.F., Fukuda, J.C., Shida, C.N., Monteiro, C.H.B., Pontinha, A.A.S., Andrade, G.G., Barbosa, O., Soares, A.P. \& Couto, H.T.Z. (2005) Inventário florestal da vegetação natural do estado de São Paulo. Imprensa Oficial, São Paulo.

Macarthur, R.H. \& Mac Arthur, J.W. (1961) On bird species diversity. Ecology, 42, 594-598.

Macarthur, R.H. (1964) Environmental factors affecting bird species diversity. The American. Naturalist, 98, 387- 397.

Manning, A.D., Fischer, J. \& Lindenmeyer, D.B. (2006) Scattered tree as keystone structures implications for conservation. Biological Conservation, 132, 311-321.

Martin, P.S., Gheler-Costa, C., Lopes, P.C., Rosalino, L.M. \& Verdade, L.M. (2012) Terrestrial non-volant small mammals in agro-silvicultural landscapes of Southeastern Brazil. Forest Ecology and Management, 282,185-195.

Marsden, S.J.,Whiffin, M. \& Galetti, M. (2001) Bird diversity and abundance in forest fragments and Eucalyptus plantations around an Atlantic forest reserve, Brazil. Biodiversity and Conservation, 10, 737-751.

Metzger, J.P., Lewinsohn, T.M., Joly, C.A., Verdade, L.M., Martinelli, L.A. \& Rodrigues, R.R. (2010) Brazilian Law: full speed in reverse? Science, 329, 276-277.

Meunier, F.D., Verheyden, C. \& Jouventin, P. (2000) Use of roadsides by diurnal raptors in agricultural landscape. Biological conservation, 92, 291-298.

Michalski, F., Norris, D. \& Peres, C. (2010) No return from biodiversity loss. Science, 232, 1282.

Motta Jr. J.C. (1990) Trophic structure and composition of three terrestrial avifaunas in central São Paulo, southeastern Brazil. Ararajuba, 1, 65-71. 
Penteado, M., Silva W.R \& Verdade, L.M. No prelo. Wildlife surveys in agricultural landscapes: Birds. Applied ecology and human dimensions on biological conservation. (edn. L.M. Verdade \& M.C. Lyra-Jorge). Springer-Verlag, Heidelberg.

Recher, H.F. \& Serventy, D.L. (1991) Long term changes in the relative abundance of birds in Kings Park, Perth, western Australia. Conservation Biology, 5, 90-102.

Renjifo, L.M. (2001) Effect of natural and anthropogenic landscape matrices on the abundance of Subandean bird species. Ecological Applications, 11, 14-31

Ribeiro, M.C., Metzger, J.P., Martensen, A.C., Ponzoni, F.J. \& Hirota, M.M., (2009) The Brazilian Atlantic Forest: how much is left, and how is the remaining forest distributed? Implications for conservation. Biological Conservation, 142, 1141-1156.

SMA - Secretaria do Meio Ambiente do Estado de São Paulo. (2009) Unidades de conservação da natureza. Governo do Estado de São Paulo.

Stallings, J.R. (1991) The importance of understory on wildlife in a Brazilian eucalypt plantation. Revista Brasileira de Zoologia, 7, 267-276.

Verdade, L.M., Rosalino, L.M. Gheler-Costa, C., Pedroso, N.M. \& Lyra-Jorge, M.C. (2011). Adaptation of mesocarnivores (Mammalia: Carnivora) to agricultural landscapes of Mediterranean Europe and Southeastern Brazil: a trophic perspective. Middle-Sized Carnivores in Agricultural Landscapes (eds L.M. Rosalino \& C. Gheler-Costa), pp.1-38. Nova Science Publishers, New York.

Vianna, L.G.G., Sato, A.M., Fernandes, M.C. \& Coelho Netto, A.L. (2007). Fronteira de expansão dos plantios de eucalipto no geoecossistema do médio vale do rio Paraíba do Sul (SP/RJ). Seminário de Recursos Hídricos da Bacia Hidrográficado Paraíba do Sul, 1, Taubaté, 2007. Anais, Taubaté, IPABHi, pp. 367-369.

Willis, E.O. (2003) Birds of eucaliptos woodlots in interior Sao Paulo. Brazilian Journal of Biology, 63, 141-158.

Zurita, G.A., Rey, N., Varela, D.M., Villagra, M.\& Bellocq, M.I. (2006) Conversion of the Atlantic Forest into native and exotic tree plantations: effects on bird communities from the local and regional perspectives. Forest Ecology and Management, 235,164-173.

Zurita, G.A. \& Bellocq, M.I. (2010) Spatial patterns of bird community similarity: bird responses to landscape composition and configuration in the Atlantic Forest. Landscape ecology, 25, 147-158. 


\section{Influence of stand level management practices and landscape context on bird occupancy in exotic Eucalyptus plantations}

\section{Introduction}

With the increasing demands for livestock and agriculture products, a substantial proportion of the ecosystems throughout the world have become devoted to the production of resources for the human society (Tilman et al., 2001). In this scenario of rapid changes in land cover and land use, the main conservation strategies have often focused on the protection of unaltered areas (Bennet et al., 2006). Although natural reserves may be important, only small and dispersed amounts of unaltered land can be protected (Musters et al., 2000; Rodrigues et al., 2004; DeFries et al., 2005). Therefore, the long-term survival of many species depends on their ability to persist in modified areas, such as urban or agricultural systems (Daily, Ehrlich \& Sánchez-Azofeita, 2001; Fischer et al., 2005; Martin et al., 2012). Consequently, monitoring and managing both natural and modified areas may be essential for conservation purposes.

Managing for wildlife conservation in modified areas, however, requires considering the landscape matrix quality from the perspective of the species in focus. In such areas, the matrix attributes can strongly influence the dynamics of population and community level processes (Gascon et al., 1999, Lindenmeyer et al., 2001; Vandemeer \& Carvajal, 2001). Considering birds, the composition and configuration of the matrix determine its suitability as a habitat (e.g., Barber et al., 2001; Vickery et al., 2001; Johnson \& Holberton, 2009) or corridor for dispersal movements (e.g., Ricketts, 2001; Baum et al., 2004). Species biological traits, such as sensitivity to habitat disturbance also influence their occurrence in the matrix (e.g., Develey \& Stouffer, 2001; Antongiovanni et al., 2005). While some generalist species are able to use different habitats, birds sensitive to fragmentation tend to prefer portions of the matrix that are structurally similar to the forest (Terborgh \& Weske, 1969) and close to it (e.g., Estades \& Temple, 1999; Luck \& Korodaj, 2008).

In recent decades, forestry plantation has rapidly expanded in tropical areas (Lugo, 1997; Carle et al., 2002). Brazil, particularly the southeastern region of the country, is a good example of the expansion of exotic plantation forests over low productivity agricultural areas (Brockerhoff et al., 2008; Martin et al., 2012). This region has been has been under human 
disturbance since the $18^{\text {th }}$ century when native vegetation (i.e. Atlantic forest and Cerrado) started being replaced by agricultural activities, such as livestock production, coffee and sugarcane plantations. Nowadays, the original vegetation is present in only $14 \%$ of its initial area (Ribeiro et al., 2009), and Eucalyptus plantations along with sugarcane production are the landscape matrices wherein natural or semi-natural forest remnants and pasture patches are immersed (Kronka et al., 2005; Rudorff \& Sugawara, 2007). Although exotic Eucalyptus plantations are poor habitats with low forest bird diversity (Motta Jr, 1990; Marsden, Whiffin \& Galetti, 2001; Zurita et al., 2006), tree plantations are more likely to contribute positively to biodiversity conservation than many other intensive land uses, such as annual crops or pastoral activities, especially if managed appropriately (Moore \& Allen, 1999; Brockerhoff et al., 2008).

Management modifications related to site preparation for planting and stand rotation, may allow for an increase in habitat structural and floristic complexity in plantation forests (Hartley, 2002). Stimulating understory development, for instance, is an easy and relatively inexpensive way to improve spatial heterogeneity within stands that may conserve or restore bird diversity in exotic Eucalyptus plantations. Besides offering breeding sites and refuges for several bird species, the understory vegetation increases food variety and availability (MacArthur \& MacArthur, 1961; Martin, 1988). Decisions about pre-commercial thinning and the initial control of competing vegetations may stimulate or maintain the understory. Silvicultural practices such as incomplete herbicide applications or or thinning in a non uniform manner can provide a mosaic of different types of habitats with relatively open or dense understory (e.g., Thomas et al., 1999; Homyack, Harrison \& Krohn, 2005). Moreover, planting or maintaining scattered native trees across the stands enhances local structural complexity increasing local bird diversity (Manning, Fischer \& Lindenmayer, 2006). These trees may provide perch, fruit, nectar and cavities for a variety of birds (e.g., Hunter \& Bond, 2001; Cockle, Martin \& Wiebe, 2010).

Several studies describe the consequences of turning great amounts of land into silviculture, but most of them focus on comparing species communities between native forest and commercial forests (e.g., Estades \& Temple, 1999; Renjifo, 2001; Barlow, et al., 2007; Zurita \& Bellocq, 2010). Some of these studies recommend possible management plans aiming to positively influence the avifauna, yet there is little empirical evidence testing the efficacy of alternative strategies for conserving or restoring bird communities in a commercial plantation context. In this study we use modeling methods to quantify species use of exotic Eucalyptus 
plantation under different management practices: the understory minimum management and the retention of scattered native trees on planted stands. Given the positive relationship between structural complexity and bird diversity (MacArthur 1964; Karr \& Roth, 1971) we expected both actions to be positively correlated with bird species occupancy. Our methodological approach, described below, explicitly deals with imperfect detection, making possible to estimate the probability of a species being present in sites where it has not been detected.

\section{Materials and methods}

\section{Study area}

We carried out this study in two farms, Três Lagoas (2322'0"S - 23²0'41'S;

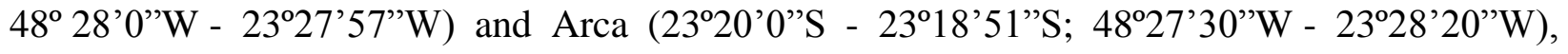
both located at Alto do Paranapanema river basin, municipality of Angatuba, State of São Paulo, southeastern Brazil. The region climate is subtropical with mean minimum temperature around $17^{\circ} \mathrm{C}$ and the mean maximum temperature of $22^{\circ} \mathrm{C}$. Annual rainfall is $1200-1500 \mathrm{~mm}$ with the driest months between April and September. The agricultural system under study has 4333 ha with the matrix composed of Eucalyptus plantation (67.7\% of the total area). According to the Brazilian Environmental Law, there are Legal Conservation Areas with native vegetation patches $(17.7 \%)$ and abandoned pastures under natural revegetation (11.1\%). The remaining area comprises rural constructions and water bodies (Fig 1).

Eucalyptus (i.e., Eucalyptus grandis, Eucalyptus urophyla and their hybrid E.urograndis) stands were planted between August 2006 and May 2008. Approximately half of the stands have no understory due to constantly management with herbicide applications in order to kill competing vegetation. The other half is under "minimum management" with vegetation regenerating since 2008. On stands under "minimum management" practice, herbicide application is restricted to the first year of the rotation cycle. Moreover, regardless of the understory management practice, several native trees that have been spared during stand preparations. The list of species includes Copaifera langsdorffii (Fabaceae), Pera obovata (Peraceae), Tabebuia alba (Bignoniaceae), Gochnatia polymorpha (Asteraceae) and Davilla elliptica (Dilleniaceae). 


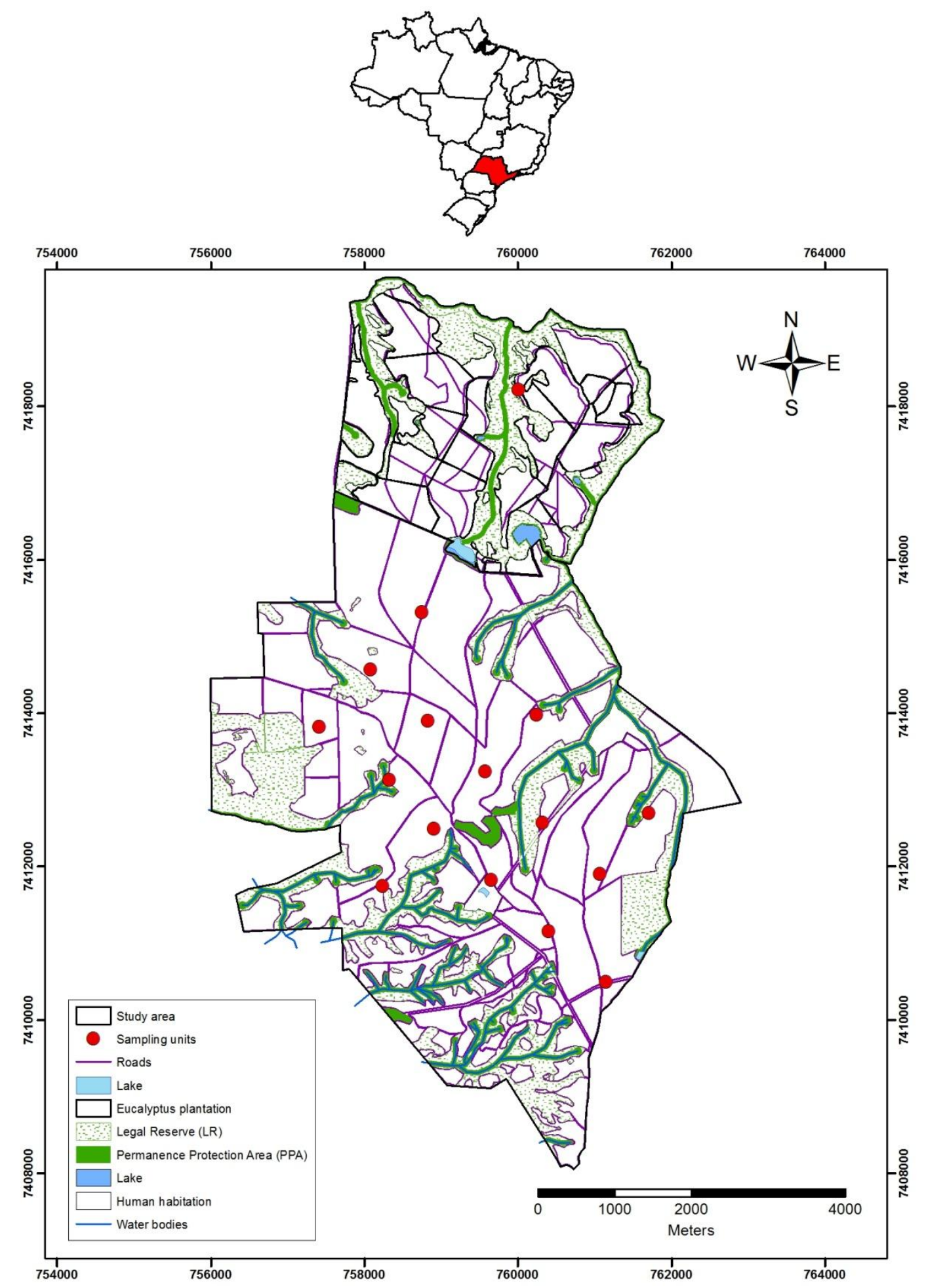

Figure 1. Study area: Três Lagoas and Arca farms. Black dots indicate the sampling units. 
Sampling design and bird counts

The sampling design is adapted from the Biodiversity Research Program (PPbio), which based on plots with 1 x $1 \mathrm{~km}$ grid spacing (Fig 1; Magnusson et al., 2005). Sampling units were placed at the grid nodules, eight within eucalyptus stands constantly managed with herbicide and eight within eucalyptus stands under minimum management. We conducted a sampling method that allows distinguishing species absences and species non-detection through temporal replicates at sampling points during a short period (Mackenzie et al., 2002). In order to do that, we visited each sampling unit daily during six consecutive days. We assumed that over this sixday survey period the system was closed (i.e. the members of the local species pool present at the study area were constant during the survey period).

Point count surveys consisted of two observers recording all birds seen or heard in 6 min within a $50 \mathrm{~m}$ detection distance (Bibby et al., 2000). We conducted observations from sunrise until 9:00 am and from 16:00 pm until sunset in early December 2011. We choose this survey period, which corresponds to the end of the breeding season in southeastern Brazil (Davis, 1946), trying to maximize bird detection when species are singing on their territories. We assessed the effect of observer variability on species detection in a preliminary analysis exploring alternative models with and without observer effect. Model comparison based on Akaike Information Criterion (AIC; Burnham \& Anderson, 2002) revealed no evidence of association between detection and observer heterogeneity (data not shown). Therefore, data from the two observers were merged in all subsequent analyses.

\section{Modeling}

We tested our hypotheses about the influence of management strategies on bird diversity using occupancy models (Mackenzie et al., 2002). These models are based on a hierarchical procedure that describes two processes affecting species detection when sampling a site: a biological process component that represents species presence in a site and a sampling process component that represents species detection at that site (e.g., Ferraz et al., 2007, Zipkin, et al., 2010; Kennedy et al., 2011) Within the biological component there is a variable $z$ denoting presence or absence of the species $i$ in the site $j$. Within the sampling component, there is a 
variable $x$ denoting the detection or non-detection of the species $i$ during $k$ multiple visits to the site $j$. Therefore, if a species is detected at least once $\left(x_{i j}>1\right)$, in a sampling occasion, then this species is present in the study site $\left(z_{i j}=1\right)$. However, if a species is not detected $\left(x_{i j}=0\right)$, there is a chance it is present, but went undetected $\left(z_{i j}=1\right)$ or is truly absent $\left(z_{i j}=0\right)$ in the study site

The $z$ values are independent outcomes of a Bernoulli process with success probability $\psi$ so that the parameter $\psi_{\mathrm{j}}$ represents the probability occupancy for the site $j$ (Dorazio \& Royle, 2005; Mackenzie et al., 2002). The patterns of detection and non-detection ( $x$ values) in multiple visits to each site are described as binomial random variables with success probability $p$ and $k$ number trials (Dorazio \& Royle, 2005; Mackenzie et al., 2002). The probability of detection ( $\mathrm{p}_{\mathrm{j}}$ ) conditioned to the probability of occupancy $\left(\psi_{\mathrm{j}}\right)$ for the site $\mathrm{j}$ composes a probabilistic term. The product of all probabilistic terms, one for every site visited in the study area, composes the model likelihood of the whole observed data. Both parameters ( $\psi$ and $p)$ can be described as logistic function of covariates.

When applied to community-level studies, occupancy modeling permits to estimate the proportion of bird species on a regional species pool that occupied our study site (Mackenzie et al., 2006) In such context, $\psi$ represents the probability of a member of the pool being present at the study site. The parameter $\psi$ can be modeled as a function of species-specific traits and the $p$ is modeled as function of site-specific traits. According to this approach, local bird species composition is explained by local habitat conditions, species features and the size of the regional species pool (Mackenzie et al., 2006; Eriksson, 1993; Cornell \& Lawton, 1992). To perform the analysis we merged data from the six visits for each site and considered each site as a sample, thereby creating eight samples for each understory management practice. For all parameter estimates we report mean, standard error and $95 \%$ confidence intervals.

We built 28 models representing different hypotheses on the influence of management practices, landscape features and individual species traits influence on bird occupancy. We did not consider all possible combinations of predictive variables, since some combinations are biologically implausible or highly correlated. We compared and selected the best models using the AIC and models with $\triangle \mathrm{AIC} \leq 2$ were considered equally plausible (Burnham \& Anderson, 2002). From the AIC values we also calculated each models weight. The AIC weight $\left(\omega_{\mathrm{i}}\right)$ provides a measure of the strength of evidence of each model relative to the whole set and the weight of the models that share a certain variable can be summed to express the relative 
importance of that variable (Burnham \& Anderson, 2002). We performed these analyses in the program PRESENCE (Hines, 2004).

Site-specific traits: management and landscape covariates

We surveyed all residual native trees within a 50 meter radius circle around the sampling site. For each tree surveyed, we determined the diameter at breast height $(\mathrm{DBH})$ and the maximum width of the crown when projected vertically to the ground. We also estimated the tree height, using a clinometer and the tree basal area, using an equation based on the circle formula $\pi \times(\mathrm{DBH} / 2)^{2}$. Finally, for each sampling site, we calculated the "tree size index" (TSI; Fischer \& Lindenmeyer, 2002a). For single trees we multiplied the values of basal area, tree height and crown width. For clumps, we multiplied the average basal area, average tree height and sum of crown widths. The TSI accounts for the attractiveness of scattered native trees on the matrix considering that birds may be responding to the size of the site instead of the number of native trees (Fischer \& Lindenmayer 2002a; Mazurek \&Zielinski, 2004; DeMars, Rosenberg \& Fontaine, 2010).

We described the understory management practice (UMP) categorically: sampling sites within stands constantly managed (0) and sampling sites in stands under minimum management understory (1). Also, in order to characterize the understory structure on sampling sites within stands under minimum management, we measured its foliage density and stratification. We established an $\mathrm{X}$ shaped sampling design in all sites and set 10 measurement stations spaced every 10 meters in each of the $\mathrm{X}$ branches. At each station we used a $2.5 \mathrm{~m}$ long stick to set a vertical column. We measured the height of all foliage that leaned on the column and then used these data to calculate the density in three strata $(0-1 \mathrm{~m} ; 1-2 \mathrm{~m} ;>2 \mathrm{~m})$. The understory description and the native tree data were limited to the same radius of birds point counts survey, so that both vegetation and bird data represented samples of 7,850 $\mathrm{m}^{2}$.

We assessed the spatial context of each sampling unit through the quantification of two landscape features, namely habitat connectivity and habitat quantity. The habitat connectivity was determined as the distance from the sampling unit to the nearest surrounding native vegetation patch. The habitat quantity was calculated as the percentage of native vegetation and natural regeneration patches within a 100 meter-radius and a 300 meter-radius around sampling 
sites. To prevent overlap between areas around distinct sampling sites we did not consider larger spatial scales. We calculated the metrics using Arc Gis 9.3 based on high-resolution photo interpretation of CBERS HRC images from 2005 (mapping scale = 1:3,000). Descriptive data of TSI, understory management practice, habitat connectivity and habitat quantity for each sampling unit are presented in (see Appendix S1 in Supporting Information).

Species-specific traits: sensitivity and foraging stratum covariates

We characterized each bird species considering its sensitivity to disturbance (SNST) and foraging stratum (STRAT) according to an ecological and distributional database (Parker et al., 1996; Appendix S2). Conforming to this classification, species included in the high sensitivity category are highly forest dependent; species in the medium sensitivity category have a moderate

degree of forest dependency, and may use open habitats. Finally, species in the low sensitivity category are positively affected by habitat alterations, being commonly associated to deforested areas and agricultural habitats. The foraging stratum was described as a binary covariate: notunderstory birds (0) and understory-birds (1). Species that uses more than one stratum, including the understory, were categorized as (1). We are aware that fitting species into categories is arbitrary and does not consider the interaction between individual traits and matrix changes through time and space. However, such categorization seems robust enough for prediction and modeling in our study system.

\section{Regional species pool}

The regional species pool is composed of 121 species (Appendix S2). This species list is based on primary data obtained from a previous survey done in the whole study area between August 2008 and June 2010 with a 1200 point count sampling effort (Millan, 2010). Since the sampling design of the present study is not appropriate to detect nocturnal and aquatic species, we excluded them from the regional pool in order to avoid $\psi$ `s underestimation. Some species of the regional pool are either exclusively or largely associated with open country areas (e.g.,Crotophaga ani, Colaptes campestris and Vanellus chilensis), others are usually associated with forested areas (e.g., Campephilus robustus, Basileuterus leucoblepharus and Platyrinchus 
mystaceus) (Sick, 1993). It is worth noting, however, that none of the species are considered to be highly forest dependent (Parker et al., 1996). Such assemblage structure, composed mostly of resilient species, is the result of the historical ecology of the area, which has been under severe human disturbance since the $19^{\text {th }}$ century (Lisboa, 2008)

\section{Results}

\section{Bird community}

We found a total of 25 species of the regional pool in the eucalyptus plantation: 18 within eucalyptus stands under minimum management and 14 within eucalyptus stands constantly managed (Appendix S2). Among these 25 species, seven were considered to have a medium sensitivity degree of forest dependency, whereas the others were considered to have low sensitivity degree of forest dependency (Appendix S2). Only, four species were considered to be understory birds. Moreover, all the species found on eucalyptus stands were a subset of those found on the regional pool (Appendix S2).

The estimate of total bird occupancy without considering imperfect species detection was 0.206 , meaning the number of species divided by the total number of species in the regional pool. But, when we consider that detection probability is less than 1 , our estimate of bird occupancy is 0.226 (CI 95\% $=0.150-0.310)$. We obtained these estimates from the null model $\psi(),. \mathrm{p}($.$) - which considers no influence from management or landscape covariates on bird$ occupancy. Evidences for differences in birds occupancy between stands under different understory management practices were weak, since differences in AIC values between the null model and the model including the UMP as single predictor was lower than 2 (Table1).

\section{Factors influencing bird occupancy}

The models including TSI and the addictive effect TSI and UMP were the best predictors among all explanatory covariates, performing better than the null model. When the $\omega_{\mathrm{i}}$ of models are summed by management covariate, UMP appears to be the least important predictor. The UMP was a poorer predictor even for understory-birds occupancy, as shown by the $\Delta$ AIC value 
of the interaction model between STRAT and UMP (Tables 1- 2). The slope parameter estimates $(\beta)$ for the effect of management actions are positively related to bird occupancy (Table 3 ). The $\beta$ estimate for TSI is significantly different of zero (i.e. 95\% CI not including zero) in all models, with or without species-specific traits included (Table 3). Otherwise, confidence interval of the $\beta$ estimate for UMP includes zero (Table 3). We found no evidence of interaction between TSI and UMP.

We found no evidence to suggest that percentage of native vegetation around the sampling site and distance to the nearest forest fragment is influencing general bird species occupancy, as show by the small differences in the $\Delta$ AIC values between the null model and models including landscape covariates. Models with interaction terms between species and landscape covariates did not have a better performance than the exclusively landscape covariate additive ones (Table 1). Among landscape models, the percentage of native vegetation area within a 100-meter radius around sampling sites is the best landscape covariate predictor of general bird species occupancy (Table 2).

We also did not reject the null hypothesis indicating that bird foraging stratum and sensitivity has no influence in bird occupancy in the study area. The single predictor model including sensitivity as a species covariate - $\psi(\operatorname{SENS}), \mathrm{p}($.$) - and the single predictor model$ separating understory birds from other species - $\psi($ STRAT), p(.) - had slightly different performances than null model (Table 1). However, due to such small difference in the $\Delta$ AIC values model with species covariates are considered to be as plausible as the null model. 
Table 1. Model selection results for the analysis that evaluated species traits and site specific influence on bird occupancy

\begin{tabular}{|c|c|c|c|c|}
\hline Models & AIC & $\Delta \mathrm{AIC}$ & $\omega_{i}$ & $\mathrm{~N}$ \\
\hline$\psi($ STRAT $), p($ TSI $)$ & 461.29 & 0.00 & 0.2703 & 4 \\
\hline$\psi(\mathrm{STRAT}), p(\mathrm{TSI}+\mathrm{UMP})$ & 461.67 & 0.38 & 0.2235 & 5 \\
\hline$\psi(),. p(\mathrm{TSI})$ & 462.41 & 1.12 & 0.1544 & 3 \\
\hline$\psi(),. p(\mathrm{TSI}+\mathrm{UMP})$ & 463.47 & 2.18 & 0.0909 & 4 \\
\hline$\psi(\mathrm{SNST}), p(\mathrm{TSI})$ & 464.31 & 3.02 & 0.0597 & 4 \\
\hline$\psi($ STRAT $), p($ FOR100) & 464.95 & 3.66 & 0.0434 & 4 \\
\hline$\psi(\mathrm{SNST}), p(\mathrm{TSI}+\mathrm{UMP})$ & 465.34 & 4.05 & 0.0357 & 5 \\
\hline$\psi(),. p(\mathrm{FOR} 100)$ & 466.08 & 4.79 & 0.0246 & 3 \\
\hline$\psi($ STRAT $), p()$. & 467.22 & 5.93 & 0.0139 & 3 \\
\hline$\psi(\mathrm{STRAT}), p(\mathrm{TSI} * \mathrm{UMP})$ & 467.59 & 6.30 & 0.0116 & 4 \\
\hline$\psi(\mathrm{SNST}), p(\mathrm{FOR} 100)$ & 467.98 & 6.69 & 0.0095 & 4 \\
\hline$\psi(),. p()$. & 468.34 & 7.05 & 0.0080 & 2 \\
\hline$\psi($ STRAT $), p($ FOR300) & 468.70 & 7.41 & 0.0066 & 4 \\
\hline$\psi(),. p(\mathrm{TSI} * \mathrm{UMP})$ & 468.71 & 7.42 & 0.0066 & 3 \\
\hline$\psi($ STRAT $), p($ DIST $)$ & 469.00 & 7.71 & 0.0057 & 4 \\
\hline$\psi(),. p(\mathrm{UMP})$ & 469.44 & 8.15 & 0.0046 & 3 \\
\hline$\psi\left(\mathrm{STRAT}^{*} \mathrm{UMP}\right), p()$. & 469.67 & 8.38 & 0.0041 & 3 \\
\hline$\psi(),. p(\mathrm{FOR} 300)$ & 469.82 & 8.53 & 0.0038 & 3 \\
\hline$\psi\left(\mathrm{SNST}^{*} \mathrm{DIST}\right), p($ ) & 470.03 & 8.74 & 0.0034 & 3 \\
\hline$\psi\left(\mathrm{SNST}^{*} \mathrm{FOR} 100\right), p()$. & 470.08 & 8.79 & 0.0033 & 3 \\
\hline$\psi(),. p(\mathrm{DIST})$ & 470.12 & 8.83 & 0.0033 & 3 \\
\hline$\psi(\mathrm{SNST}), p()$. & 470.24 & 8.95 & 0.0031 & 3 \\
\hline$\psi\left(\mathrm{SNST}^{*} \mathrm{FOR} 300\right), p()$. & 470.34 & 9.05 & 0.0029 & 3 \\
\hline$\psi(\mathrm{SNST}), p(\mathrm{TSI} * \mathrm{UMP})$ & 470.61 & 9.32 & 0.0026 & 4 \\
\hline$\psi(\mathrm{SNST}), p(\mathrm{UMP})$ & 471.32 & 10.03 & 0.0018 & 4 \\
\hline$\psi(\mathrm{SNST}), p(\mathrm{FOR} 300)$ & 471.72 & 10.43 & 0.0015 & 4 \\
\hline$\psi(\mathrm{SNST}), p(\mathrm{DIST})$ & 472.02 & 10.73 & 0.0013 & 4 \\
\hline
\end{tabular}

Covariate codes for $\psi$ : SNST= sensitivity to disturbance; STRAT= foraging stratum.

Covariate codes for $p$ : FOR100 = forest cover in buffer size of 100 meters radium; FOR300 $=$ forest cover in buffer size of 300 meter radium; DIST $=$ distance to the nearest forest patch; UMP= understory management practice; TSI= tree size index.

Models with no covariates, i.e., null models are indicated as ( . ).

The operators + and $*$ indicate addictive and interactive effects, respectively.

$\mathrm{N}$ : number of parameters of the models 
Table 2. Relative importance of site-specific covariates on bird occupancy. Relative importance values are the sum of Akaike weight of all models containing a particular covariate.

\begin{tabular}{lc}
\hline \multicolumn{1}{c}{ Site specific traits } & $\boldsymbol{\omega}_{\mathbf{i}}$ \\
\hline Management practices & \\
Scattered tree retention (TSI) & 0.851 \\
Understory minimum management (UMP) & 0.484 \\
\hline Landscape context & \\
\hline Forest cover (FOR100) & 0.083 \\
Forest cover (FOR300) & 0.013 \\
Distance to forest patch (DIST) & 0.011 \\
\hline
\end{tabular}

Table 3. Site-specific estimates of slope coefficients for best performing models.

\begin{tabular}{|c|c|c|c|c|c|c|}
\hline \multirow[t]{3}{*}{ Model } & \multirow[t]{3}{*}{ AIC } & \multirow[t]{3}{*}{$\triangle \mathrm{AIC}$} & \multicolumn{4}{|c|}{ Site-specific covariates } \\
\hline & & & \multicolumn{2}{|r|}{ TSI } & \multicolumn{2}{|c|}{ UMP } \\
\hline & & & Estimate & $\mathrm{Cl}_{95 \%}$ & Estimate & $\mathrm{Cl}_{95 \%}$ \\
\hline$\psi(\mathrm{STRAT}), p(\mathrm{TSI})$ & 461.29 & 0.00 & 0.361 & 0.119-0.606 & - & - \\
\hline$\psi(\mathrm{STRAT}), p(\mathrm{TSI}+\mathrm{UMP})$ & 461.67 & 0.38 & 0.363 & 0.117-0.604 & 0.503 & $-0.241-1.247$ \\
\hline$\psi(),. p(\mathrm{TSI})$ & 462.41 & 1.12 & 0.361 & 0.119-0.606 & - & - \\
\hline
\end{tabular}

C195\%: indicates approximate 95\% confidence intervals, assuming that parameter estimates are normally distributed.

\section{Discussion}

Our results show that the major factor associated with differences in bird occupancy within exotic Eucalyptus plantations is the management strategy adopted during site preparation for planting and initial control of competing vegetation. Estimates of bird occupancy were consistently higher in stands that presented scattered native trees. The presence of scattered native trees within mature eucalyptus stands was associated with an increase in the proportion of bird species from the regional pool that was able to occupy the landscape matrix. Moreover, stands that presented regenerating understory also had positive, although relatively smaller, effect on bird occupancy. In the next sections, we explore these results in more details and discuss their implications for bird conservation in silvicultural plantations. 


\section{Influence of stand level management practices}

The positive influence of scattered trees on bird occupancy in human-modified landscapes may be related to the fact that these trees can offer greater structural complexity relative to its surrounds (Manning, Fischer \& Lindenmeyer, 2006). In open areas such as young homogenous stands or regenerating clear-cut stands, retained isolated trees might be the only arboreal elements in miles, so they represent roosting, resting and foraging habitats several forest bird species moving between forest patches (e.g., Harvey et al., 2006). Moreover, trees in commercial silviculture are selected to have reduced complexity, features such as stem straightness and little branching for incrementing productivity (Smith et al., 1997). Thus, in mature silvicultural plantations, scattered native trees might be more attractive to birds because they present structural features that fully grown commercial trees do not, such as large horizontal limbs, hollows or cavities for nests.

Approximately 50\% of scattered trees in the study area species are either pollinated or dispersed by birds (Athayde, 2012) suggesting that these trees may also be attractive as food resources. Some frugivorous and omnivorous species detected exclusively on stand with relatively higher tree size index (e.g., Tangara sayaca, Tangara cayana, Elaenia flavogaster and Patagioenas cayennensis) may be using these fruiting trees as an alternative foraging place. Some studies have shown that isolated freshly fruiting trees in agricultural landscapes provide important resources for birds (Luck \& Daily, 2003; Sekercioglu et al., 2007). Although only species that are good dispersers and ecological generalists may able to consume fruits and disperse seeds (Laurance \& Yensen, 1991)

Our results also showed that even an undeveloped understory (under natural regeneration for three years), which is composed mainly of herbaceous plants and sparse shrubs can increase bird occupancy. This finding indicates that commercial thinning practices may be effective in rapidly promoting an increase in bird diversity. Such relationship can be attributed to the effect of the increment on vertical structural complexity, with the addition of a new foliage layer providing extra food sources and foraging niches (MacArthur \& MacArthur, 1961). It might also be attributed to the effect of an increment on horizontal structural complexity, due to the patchy distribution of such resources (Roth, 1976) However, when we compared species composition among stand types, we found no significant relation between the understory management 
practice and understory bird occupancy. This lack of relation suggests that, despite positively related overall bird occupancy, an early understory successional stage does not provide minimum habitat requirements to attract other than generalist species from adjacent remnant forests into eucalyptus areas.

Successional changes may strongly influence species diversity and composition in plantation forests (e.g., Lencinas, et al., 2009; McDermott \& Wood, 2009). Although general responses of bird community to management strategies that stimulate understory regeneration are positive, the potential magnitude of the effect might be conditioned the rotation cycle length. In plantations with relatively short rotation cycles the time for understory regeneration might not be long enough to provide a suitable habitat for more specialized species. Otherwise, old exotic plantations with a fully developed understory beneath mature trees have been reported to present high species diversity with similar composition to that of native forests (Willis, 2003). Considering that most plantations in tropical and subtropical countries are composed of exotic trees species that are managed in short cycles (e.g., 5-10 years from planting to harvesting; Evans \& Turnbull, 2004; Cossalter \& Pye-Smith, 2003) management strategies intended to increase bird diversity in such areas should focus not only on understory management practices. Our results imply that a multiple approach, including the retention of native scattered, achieves better results.

\section{Influence of landscape context}

Models including landscape covariates were among the worst performing models, suggesting a relatively minor effect of such factors on bird occupancy in our study area. The absence of distance effect on bird occupancy suggests that, in the spatial scale we studied, the eucalyptus matrix may not be fully unsuitable to dispersal for habitat complementation or movement of some species found on the regional pool. This seems reasonable considering that species have varying habitat requirements (e.g., Devictor, 2008) and in and differ considerably their dispersal ability (e.g., Boscolo \& Metzger, 2009). Native forest cover in a 100-meter buffer is the best predictor among all landscape covariates we investigated. Nevertheless it seems to have a relatively small effect of on bird occupancy when compared to stand site features. This might be attributed to the fact that most of species found on eucalyptus stands are considered to be more 
resilient to habitat disturbance. However, even if the percentage of vegetation around a sampling unit does not reflect the variability in site-specific bird occupancy, the fact that species found on eucalyptus stands are subset of species found in the regional species pool suggests the importance of native vegetation patches as sources of species to eucalyptus areas. It also suggests the value of such areas to maintain and increase overall bird diversity in human-modified areas.

\section{Implications for conservation}

Conservation biologists are increasingly aware of the importance to create management solutions that combine conservation with production goals within agricultural lands. In areas where most of the natural habitat has already been converted into agricultural production systems, raising the quality of the matrix is crucial for maintaining the remaining biodiversity. Therefore, understanding the relationships between structural features of different agricultural matrices and species diversity, and also empirically comparing traditional management practices with those that are potentially benefit wildlife can improve the efficacy of conservation efforts in the protection of biodiversity.

Our results support the idea that plantation managers interested in improving environmental conditions for bird occupancy in Eucalyptus plantations may focus on strategies that manipulate stand-level structural attributes. There are different practices that can alter understory successional dynamics and create an opportunities to attract some species into plantations during production cycle. To increase the potential positive effect of understory regeneration in bird diversity, we suggest maximizing vertical and horizontal structural complexity within and among stands, stimulating an irregular pattern of regeneration and development of herbs, shrubs and other foliage layers. Such spatial heterogeneity can be achieved through restricting herbicide applications and different thinning regimes during initial site preparation for plantation and also during stand rotation with none or little loss of production (Barbour et al., 1997).

We have shown that bird occupancy increased even in an early successional stage understory. However, based on our results we can also affirm that in order to optimize the efficacy of conservation effort in short length rotation cycles and direct stand development to 
greater structural complexity, complementary management practices should be considered. The retention of native mature trees scattered on plantation stands, for instance, can have a comparatively higher influence in attracting bird species probably due to its local function as perching, foraging and nesting habitat for several species. Moreover, in a broader scale, maintaining native scattered trees in agricultural lands may also promote structural and functional connectivity among reminiscent native forest patches (e.g., Fischer \& Lindenmeyer, 2002b; Boscolo et al., 2008), especially in low resistance matrices (Baum et al., 2004; Uezu, Beyer \& Metzger, 2008)) Therefore, our results suggest that preserving existing trees and fomenting the recruitment of younger replacement trees in Eucalyptus stands along with practices that trigger understory regeneration will improve matrix suitability to bird species.

\section{Acknowledgments}

We thank A.P.R.P., F.T.R.O. and A.B. for help in the fieldwork; T.N.A and I.R. for help with landscape analysis; G.F. for methodological advices; G.M. for great discussions and comments on the manuscript. Financial support was provided by FAPESP, CNPq, Capes and Ripasa S.A. Papel e Celulose.

\section{References}

Antongiovanni, M. \& Metzger, J.P. (2005) Influence of matrix habitats on the occurrence of insectivorous bird species in Amazonian forest fragments. Biological Conservation, 122, 441-451.

Athayde, E. A. (2012) Importância da heterogeneidade natural na conservação da biodiversidade de aves em paisagem agrosilvicultural. $\mathrm{PhD}$ Thesis. University of São Paulo.

Barber, D.R., Martin, T.E., Melchiors, M.A., Thill, R.E. \& Wigleys, T.B. (2001) Nesting success of birds in different silvicultural treatments in southeastern U.S. pine forests. Conservation Biology, 15, 196-207.

Barbour, R.J., Johnston,S., Hayes J.O. \& Tucker, G.F. (1997) Simulated stand characteristics and wood product yields from Douglas-fir plantations managed for ecosystem objectives. Forest Ecology and Management, 91, 205-219. 
Barlow, J., Mestre, L.A.M., Gardner, T.A. \& Peres, C.A. (2007) The value of primary, secondary and plantation forests for Amazonian birds. Biological Conservation, 136, 212-231.

Baum, K.A., Haynes, K.J., Dillemuth, F.P. \& Cronin, J.T. (2004) The matrix enhances the effectiveness of corridors and stepping stones. Ecology, 85, 2671-2676.

Bennet, A.F., Radford, J.Q. \& Haslem, A. (2006) Properties of land mosaics: implications for nature conservation in agricultural environments. Biological Conservation, 133, 250-264.

Bibby, C., Burguess, N.D, Hill, D.A., Mustoe, S.H. (2000) Bird Census Techniques, 2nd edn. Elsevier, London

Boscolo, D., Candia-Gallardo C., Awade, M. \& Metzger, J.P. (2008) Importance of interhabitat gaps and stepping-stones for lesser woodcreepers (Xiphorhynchus fuscus) in the Atlantic Forest, Brazil. Biotropica, 40, 273-276.

Boscolo, D. \& Metzger, J.P. (2009) Is bird incidence in Atlantic forest fragments influenced by ladscape patterns at multiple scales? Landscape Ecology, 24, 907-918.

Brockerhoff, E.G., Jactel, H., Parrotta, J.A., Quine, C.P. \& Sayer, J. (2008) Plantation forests and biodiversity: oxymoron or opportunity. Biodiversity and Conservation, 17, 925-951.

Burnham, K. P., Anderson, D.R. (2002) Model selection and multimodel inference: a practical information-theoretic approach, 2nd edn. Springer-Verlag, New York.

Carle, J., Vuorinen, P. \& Del Lungo, A. (2002). Status and trends in global forest plantation development. Journal Forest Products, 52, 1-13.

Cockle, K. , Martin, K.\& Wiebe, K. (2010) Selection of nest trees by cavity-nesting birds in the neotropical Atlantic Forest. Biotropica, 43, 228-236

Cornell, H. V. \& Lawton, J. H. (1992) Species interactions, local and regional processes, and limits to the richness of ecological communities: a theoretical perspective. Journal of Animal Ecology, 61, 1-12.

Cossalter C \& Pye-Smith, C. (2003) Fast-wood forestry - myths and realities. Center for International Forestry Research, Jakarta.

Daily, G.C., Ehrlich, P.R \& Sánchez - Azofeita, A. (2001) Countryside biogeography: use of human-dominated habitats by the avifauna of southern Costa Rica. Ecological Applications, 11, 1-13.

Davis, D.E. (1946) A seasonal analysis of mixed flocks of birds in Brazil. Ecology, 27, 168-181. 
Defries, R. Hansen, A. Newton, A.C. \& Hansen, M.C. (2005) Increasing isolation of protected areas in tropical forests over the past twenty years. Ecological Applications, 15, 19-26.

Demars, C.A., Rosenberg, D.K. \& Fontaine, J.B. (2010) Multi-scale factor affecting bird use of isolated remnant oak trees in agro- ecosystems. Biological Conservation, 143, 1485-1492.

Develey, P.F \& Stouffer, P.C. (2001) Effect of roads on movements by understory birds in mixed species flocks in central Amazonia Brazil. Conservation Biology, 15, 1416-1422.

Devictor, V., Julliard, R., Jiguet, F. \& Couvet, D. (2008) Distributions of specialists and generalist species along spatial gradients of habitat disturbance and fragmentation. Oikos, 11, 507-514.

Dorazio, R. M. \& Royle, A. (2005) Estimating size and composition of biological communities by modeling the occurrence of species. Journal of the American Statistical Association, 100, 389-398.

Eriksson, O. (1993) The species-pool hypothesis and plant community diversity. Oikos, 68, 371-374.

Estades, C. N. \& Temple, S.A. (1999) Deciduous bird communities in a fragmented landscape dominated by exotic pine plantations. Ecological applications, 9, 573-585.

Evans, J. \& Turnbull, J.W. (2004) Plantation Forestry in the Tropics, 3rd edn. Oxford University Press, Oxford.

Ferraz, G., Nichols, J.D., Hines, J.E., Stouffer, P.C., Bierregard, R.O. \& Lovejoy, T.E. (2007) A large-scale deforestation experiment: effects of patch area and isolation on Amazon birds. Science, 315, 238-240.

Fischer, J. \& Lindenmeyer, D.B. (2002a) The conservation value of paddock trees for birds in a variegated landscape in southern New South Wales. Species compositions and site occupancy patterns. Biodiversity and Conservation, 11, 807-832.

Fischer, J. \& Lindenmayer D.B. (2002b) The conservation value of paddock trees for birds in a variegated landscape in southern New South Wales.2. Paddock trees as stepping stones Biodiversity and Conservation, 11, 833-849.

Fischer, J., Fazey, I., Briese, R. \& Lindenmeyer, D.B. (2005) Making matrix matter: challenges in Australian grazing landscapes. Biodiversity and Conservation, 97, 71-88. 
Gascon, C., Lovejoy, T.E., Bierregaard Jr., R.O., Malcolm, J.R., Stouffer, P.C., Vasconcelos, H.L., Laurance, W.F., Zimmerman, B., Tocher, M.\& Borges, S. (1999) Matrix habitat and species richness in tropical forest remnants. Biological Conservation, 91, 223-229.

Hartley, M.J. (2002) Rationale methods for conserving biodiversity in plantation forests. Forest Ecology and Management, 15, 81-95.

Harvey, C.A., Medina, A., Sanchez, D.M., Vilchez, S., Hernadez, B., Saenz, J.C., Maes, J.M., Casanoves, F.\& Sinclair, F.L. (2006). Patterns of animal diversity in different forms of tree cover in agricultural landscapes. Ecological Applications, 16, 1986-1999.

Hines, J.E. (2004) Presence 2.0. Laurel: USGS - Patuxent Wildlife Research Center. Available at http://www.mbrpwrc.usgs.gov/software/presence.html (accessed 04/31/2011).

Homyack, J.A., Harrison, D.J. \& Krohn, W.B. (2005) Long-term effects of precommercial thinning on small mammals in northern Maine. Forest Ecology and Management, 205, 43-57.

Hunter, J.E. \& Bond, M.L. (2001) Residual trees: wildlife associations and recommendations. Wildlife Society Bulletin, 29, 995-999.

Johnston, J.C. \& Holberton, R.L. (2009) Forest management and temporal effects on food abundance for a ground-foraging bird (Catharus guttatus). Forest Ecology and Management, 258, 1516-1527.

Karr, J.R \& Roth, R.R. (1971) Vegetation structure and avian diversity in several New World areas. The American Naturalist, 105, 423- 435.

Kennedy, C.M., Campbell Grant, E.H., Neel, M.C., Fagan, W.F. \& Marra. P.P. (2011) Landscape matrix mediates occupancy dynamics of neotropical avian insectivores. Ecological Applications, 21, 1837-1850.

Kronka, F. J. N., Nalon, M.A., Matsukuma, C.K., Kanashiro, M.M, Ywane, M.S.S., Pavão, M., Durigan,G., Lima, L.M.P.R., Guillaumon, J.R., Baitello, J.B., Borgo, S.C., Manetti, L.A., Barradas, A.M.F., Fukuda, J.C., Shida, C.N., Monteiro, C.H.B., Pontinha, A.A.S., Andrade, G.G., Barbosa, O., Soares, A.P. \& Couto, H.T.Z. (2005) Inventário florestal da vegetação natural do estado de São Paulo. Imprensa Oficial, São Paulo.

Laurance, W.F. \& Yensen, E. (1991) Predicting the impacts of edge effects in fragmented habitats. Biological Conservation, 55, 77-92. 
Lencinas, M.V., Pastur, G.M., Gallo, E. \& Cellinni, J.M. (2009) Alternative silvicultural practices with variable restention improve bird conservtion in managed South Patagonian forests. Forest Ecology and Management, 258, 472-480.

Lindenmayer, D.B., Cunningham, R.B., Macgregor, C., Tribolet, C. \& Donelly, C.F. (2001) A prospective longitudinal study of landscape matrix effects on fauna in woodland remnants: experimental design and baseline data. Biological Conservation, 101, 157-169.

Lisboa, M.A.M.(2008) A política dos coronéis e a difusão do ensino primário em Angatuba/SP (1870-1930). PhD. Thesis, University of Campinas.

Luck, G.W. \& Daily, G. C. (2003) Tropical countryside bird assemblages: richness, compostion and foraging differ by landscape context. Ecological applications, 13, 235-247.

Luck, G.W. \& Korodaj, T.N. (2008) Stand and landscape-level factors related to bird assemblages in exotic pine plantations: implications for forest management. Forest Ecology and Management, 255, 2688-2699.

Lugo, A.E. (1997) The apparent paradox of reestablishing species richness on degraded lands with tree monocultures. Forest Ecology and Management, 99, 9-19.

Macarthur, R.H. \& Mac Arthur, J.W. (1961) On bird species diversity. Ecology, 42, 594-598.

Macarthur, R.H. (1964) Environmental factors affecting bird species diversity. The American. Naturalist, 98, 387- 397.

Mackenzie, D.I., Nichols, J.D. Lachman, G.B., Droege, S., Royle, J.A. \& Langtimm, C.A. (2002) Estimating site occupancy rates when detection probabilities are less than one. Ecology, 83, 2248-2255.

Mackenzie, D.I., Nichols, J.D., Royle, J.A., Pollock, K.H., Bailey, L.L. \& Hines, J.E. (2006) Occupancy in community-level studies. Occupancy estimation and modeling: inferring patterns and dynamics of species occurrence (eds D.I Mackenzie, J.D. Nichols, J.A. Royle, K.H. Pollock, L.L. Bailey \& J.E. Hines), pp. 2449-265. Elsevier, San Diego.

Magnusson, W.E., Lima, A.P., Luizão, R., Luizão, F., Costa, F.R.C., Castilho, C.V. \& Kinupp, V.F. (2005) RAPELD: a modification of the Gentry method for biodiversity surveys in long-term ecological research sites. Biota Neotropica, 5, 19-24.

Manning, A.D., Fischer, J. \& Lindenmeyer, D.B. (2006) Scattered tree as keystone structures implications for conservation. Biological Conservation, 132, 311-321. 
Marsden, S.J.,Whiffin, M. \& Galetti, M. (2001) Bird diversity and abundance in forest fragments and Eucalyptus plantations around an Atlantic forest reserve, Brazil. Biodiversity and Conservation, 10, 737-751.

Martin, T.E. (1988) Habitat and area effects on forest bird assemblages: is nest predation an influence? Ecology, 69, 74-84.

Martin, P.S., Gheler-Costa, C., Lopes, P.C., Rosalino, L.M. \& Verdade, L.M. (2012) Terrestrial non-volant small mammals in agro-silvicultural landscapes of Southeastern Brazil. Forest Ecology and Management, 282,185-195.

Mazurek, M.J., Zielinski, W.J. (2004) Individual legacy trees influence vertebrate wildlife diversity in commercial forests. Forest Ecology and Management, 193, 321-324.

McDermott, M.E. \& Wood, P.B. (2009) Short- and long-term implications of clearcut and twoage silviculture for conservation of breeding forest birds in the central Appalachians, USA. Biological Conservation, 142, 212-220.

Millan, C.H. (2010) Distribuição e abundância de aves em áreas de silvicultura de eucalipto na Bacia do Paranapanema, São Paulo, Brasil. Undergraduate thesis. University of São Paulo.

Moore, S.E. \& Allen, H.L. (1999) Plantation forestry. Maintaining biodiversity in forest ecosystems (ed M.L. Hunter), pp. 400-433. Cambridge University Press, New York.

Motta Jr. J.C. (1990) Trophic structure and composition of three terrestrial avifaunas in central São Paulo, southeastern Brazil. Ararajuba, 1, 65-71.

Musters, C.J.M., Degraaf, J.H. \& Terkeurs, W.J. (2000) Can protected areas be expanded in Africa? Science, 287, 1759-1760.

Parker III, T.A., Stotz, D.F. \& Fitzpatrick, J.W. (1996) Ecological and Distributional databases. Neotropical birds: ecology and conservation (eds D.F. Stotz, J.W. Fitzpatrick ,T.A. Parker III \& D.K. Moskovits), pp. 131-293.Chicago Press, Chicago.

Renjifo, L.M. (2001) Effect of natural and anthropogenic landscape matrices on the abundance of Subandean bird species. Ecological Applications, 11, 14-31.

Ribeiro, M.C., Metzger, J.P., Martensen, A.C., Ponzoni, F.J. \& Hirota, M.M., (2009) The Brazilian Atlantic Forest: how much is left, and how is the remaining forest distributed? Implications for conservation. Biological Conservation, 142, 1141-1156. 
Ricketts, T.H. (2001) The matrix matters: effective isolation in fragmented landscapes. The American Naturalist, 158, 87-99.

Rodrigues, A.S. L., Andelman, S.J., Bakar, M.I., Boitani, L., Brooks, T.M., Cowling, R.M., Fishpool, L.D.C., Fonseca, G.A.B., Gaston, K.J., Hoffmann, M., Long, J.S., Marquet, P.A., Pilgrim, J.D., Pressey, R.L., Schipper, J., Sechrest, W., Stuart, S.N., Underhill, L.G., Waller, R..W., Watts, M.E.J. \& Yan, X. (2004) Effectiveness of the global protected area network in representing species diversity. Nature, 428, 640-643.

Roth, R.R. (1976) Spatial heterogeneity and bird species diversity. Ecology, 57, 773-782.

Rudoorff, B.F.T. \& Sugawara, L.M. (2007) Mapeamento da cana-de-açúcar na região Centro-Sul via imagens de satélites. Informe Agropecuário, 28, 79-86.

Sekercioglu, C.H., Loarie, S.R., Brenes, F.O., Ehrlich, P.R. \& Daily, G.C. (2007) Persistence of forest birds in the Costa Rican agricultural countryside. Conservation Biology, 21, 482494.

Sick. H. (1993) Birds in Brazil: a natural history. Princeton University Press, Princeton, New Jersey.

Smith, D.M., Larson, B.C., Kelty, M.J. \& Ashton, P.M.S. (1997) The Practice of Silviculture: applied forest ecology. Wiley, New York.

Terborgh, J.\& Weske, J.S (1969) Colonization of secondary habitats by Peruvian birds. Ecology, 50, 765-782.

Thomas, S.C., Halpern, C.B., Falk, D.A., Liguori, D.A. \& Austin, K.A. (1999). Plant diversity in managed forests: understory responses to thinning and fertilization. Ecological Applications, 9, 864-879.

Tilman, D., Fargione, J., Wolff, B., D'antonio, C., Dobson, A., Howarth, R., Schindler, D., Schlesinger, W.H., Simberloff, D. \& Swackhamer, D. (2001) Forescasting agriculturally driven global environmental change. Science, 292, 281-284.

Uezu, A., Beyer, D.D \& Metzger, J.P. (2008) Can agroforest woodlots work as stepping stones for birds in the Atlantic forest region? Biodiversity Conservation, 17, 1907-1922.

Vandermeer, J \& Carvajal R. (2001) Metapopulation dynamics and the quality of the matrix. The American Naturalist, 158, 211-220.

Vickery, J.A., Tallowin, J.R., Feber, R.E., Asteraki, E.J., Atkinson, P.W., Fuller, R.J. \& Brown V.K. (2001) The management of lowland neutral grasslands in Britain: effects of 
agricultural practices on birds and their food resources. Journal of Applied Ecology, 38, 647-664.

Willis, E.O. (2003) Birds of eucaliptos woodlots in interior Sao Paulo. Brazilian Journal of Biology, 63, 141-158.

Zipkin, E.F., Dewan, A. \& Royle, J.A (2009) Impacts of forest fragmentation on species richness: a hierarchical approach to community modeling. Journal of Applied Ecology, 46, 815-822.

Zurita, G.A., Rey, N., Varela, D.M., Villagra, M.\& Bellocq, M.I. (2006) Conversion of the Atlantic Forest into native and exotic tree plantations: effects on bird communities from the local and regional perspectives. Forest Ecology and Management, 235, 164-173.

Zurita, G.A. \& Bellocq, M.I. (2010) Spatial patterns of bird community similarity: bird responses to landscape composition and configuration in the Atlantic Forest. Landscape ecology, 25, 147-158. 


\section{Supporting information}

Table S1. Descriptive data of TSI, understory management practice, habitat connectivity and habitat quantity for each sampling unit.

\begin{tabular}{cccccc}
\hline S.U & TSI & UMP & DIST & FOR100 & FOR300 \\
\hline 1 & 0 & 0 & 539 & 0.00 & 10.40 \\
\hline 2 & 0 & 0 & 464 & 0.00 & 27.63 \\
3 & 0 & 0 & 669 & 0.00 & 0.00 \\
\hline 4 & 37 & 0 & 621 & 0.00 & 0.00 \\
\hline 5 & 608 & 1 & 297 & 47.40 & 34.61 \\
6 & 0 & 0 & 665 & 0.00 & 0.00 \\
\hline 7 & 0 & 1 & 423 & 20.93 & 36.29 \\
\hline 8 & 135 & 1 & 529 & 0 & 8.05 \\
9 & 82 & 1 & 596 & 0 & 0 \\
\hline 10 & 0 & 1 & 489 & 0.21 & 13.46 \\
\hline 11 & 948 & 0 & 595 & 47.76 & 26.28 \\
\hline 12 & 743 & 1 & 420 & 24.02 & 35.78 \\
13 & 0 & 0 & 574 & 0 & 0 \\
\hline 14 & 1287 & 1 & 570 & 0 & 0 \\
15 & 0 & 1 & 435 & 23.4 & 32.3 \\
\hline 16 & 0 & 0 & 605 & 16.27 & 5.39 \\
\hline
\end{tabular}

S.U: sampling unit number; TSI: tree size index; UMP: understory management practice; ; DIST: distance to the nearest forest patch (m); FOR100:forest cover in buffer size of 100 meters radium; FOR300: forest cover in buffer size of 300 meter radium.

Table S2. Regional species pool list. Species are categorized considering its sensitivity to disturbance (SNST) and foraging stratum (STRAT). Species within lines in bold were detected at least once during sampling survey.

\begin{tabular}{lrr}
\hline \multicolumn{1}{c}{ Species } & SNST & STRAT \\
\hline Crypturellus parvirostris & 0 & 0 \\
Crypturellus tataupa & 0 & 0 \\
Penelope superciliaris & 1 & 0 \\
Cariama cristata & 1 & 0 \\
Vanellus chilensis & 0 & 0 \\
Buteogallus meridionalis & 0 & 0
\end{tabular}




\begin{tabular}{|c|c|c|}
\hline Species & SNST & STRAT \\
\hline Elanus leucurus & 0 & 0 \\
\hline Falco sparverius & 0 & 0 \\
\hline Falco femoralis & 0 & 0 \\
\hline Milvago chimachima & 0 & 0 \\
\hline Caracara plancus & 0 & 0 \\
\hline Herpetotheres cachinnans & 0 & 0 \\
\hline Patagioenas picazuro & 1 & 0 \\
\hline Patagioenas cayennensis & 1 & 0 \\
\hline Columbina talpacoti & 0 & 0 \\
\hline Leptotila rufaxila & 1 & 0 \\
\hline Leptotila verreauxi & 0 & 1 \\
\hline Zenaida auriculata & 0 & 0 \\
\hline Crotophaga ani & 0 & 0 \\
\hline Guira guira & 0 & 0 \\
\hline Tapera naevia & 0 & 1 \\
\hline Crotophaga major & 1 & 0 \\
\hline Piaya cayana & 0 & 0 \\
\hline Amazona aestiva & 1 & 0 \\
\hline Forpus xanthopterigius & 1 & 0 \\
\hline Anthracothorax nigricollis & 0 & 0 \\
\hline Phaetornis petrei & 0 & 0 \\
\hline Eupetomena macroura & 0 & 1 \\
\hline Thalurania glaucopis & 1 & 1 \\
\hline Leucochloris albicollis & 0 & 1 \\
\hline Chlorostilbon lucidus & 0 & 1 \\
\hline Trogon surrucura & 1 & 0 \\
\hline Malacoptila striata & 1 & 1 \\
\hline Ramphastos toco & 1 & 0 \\
\hline Celeus flavescens & 0 & 0 \\
\hline Colaptes campestris & 0 & 0 \\
\hline Colaptes melanochloros & 0 & 0 \\
\hline Dryocopus lineatus & 0 & 0 \\
\hline Campephilus robustus & 1 & 0 \\
\hline Melanerpes candidus & 0 & 0 \\
\hline Picumnus temninckii & 1 & 0 \\
\hline Sittassomus griseicapillus & 1 & 0 \\
\hline Lepidocolaptes angustirostris & 1 & 1 \\
\hline Annumbius annumbi & 1 & 0 \\
\hline Automolus leucophthalmus & 1 & 1 \\
\hline Furnarius rufus & 0 & 0 \\
\hline Lochmias nematura & 1 & 0 \\
\hline
\end{tabular}




\begin{tabular}{|c|c|c|}
\hline Species & SNST & STRAT \\
\hline Synallaxis ruficapilla & 1 & 1 \\
\hline Dysithamnus mentalis & 1 & 1 \\
\hline Thamnophillus caerulescens & 0 & 1 \\
\hline Thamnophillus doliatus & 0 & 1 \\
\hline Conopophaga lineata & 1 & 1 \\
\hline Platyrinchus mystaceus & 1 & 1 \\
\hline Elaenia chiriquensis & 0 & 0 \\
\hline Elaenia flavogaster & 0 & 0 \\
\hline Elaenia mesoleuca & 0 & 0 \\
\hline Campotostoma obsoletum & 0 & 0 \\
\hline Serpophaga subcristata & 0 & 0 \\
\hline Phaeomyias murina & 0 & 0 \\
\hline Tolmomyias sulphurescens & 1 & 0 \\
\hline Knipolegus cyanirostris & 0 & 0 \\
\hline Xolmis velatus & 1 & 1 \\
\hline Tyrannus savanna & 0 & 0 \\
\hline Tyrannus melancholicus & 0 & 0 \\
\hline Megarynchus pitangua & 0 & 0 \\
\hline Pitangus sulphuratus & 0 & 0 \\
\hline Myiodinastes maculatus & 0 & 0 \\
\hline Myiarchus swainsoni & 0 & 0 \\
\hline Pachyramphus polychopterus & 0 & 0 \\
\hline Corythopis delalandi & 1 & 0 \\
\hline Todirostrum poliocephalum & 0 & 0 \\
\hline Todirostrum cinereum & 0 & 1 \\
\hline Empidonomus varius & 0 & 0 \\
\hline Machetornis rixosa & 0 & 0 \\
\hline Cyanocorax cristatellus & 1 & 0 \\
\hline Cyanocorax chrysops & 0 & 0 \\
\hline Chiroxiphia caudata & 0 & 1 \\
\hline Vireo olivaceus & 0 & 0 \\
\hline Cyclarhis gujanensis & 0 & 0 \\
\hline Progne tapera & 0 & 0 \\
\hline Pygochelidon cyanoleuca & 0 & 0 \\
\hline Tachycineta leucorrhoa & 0 & 0 \\
\hline Troglodytes musculus & 0 & 0 \\
\hline Mimus saturninus & 0 & 0 \\
\hline Turdus albicollis & 1 & 1 \\
\hline Turdus amaurochalinus & 0 & 0 \\
\hline Turdus leucomelas & 0 & 0 \\
\hline Turdus rufiventris & 0 & 0 \\
\hline Turdis subalaris & 1 & 1 \\
\hline
\end{tabular}




\begin{tabular}{lrr}
\hline \multicolumn{1}{c}{ Species } & SNST & STRAT \\
\hline Tangara sayaca & 0 & 0 \\
Dacnis cayana & 0 & 0 \\
Piranga flava & 0 & 0 \\
Tangara cayana & 1 & 1 \\
Lanio cucullatus & 0 & 1 \\
Tachyphonuns coronatus & 0 & 0 \\
Zonotrichia capensis & 0 & 0 \\
Carduellis magellanica & 0 & 0 \\
Sporophila caerulescens & 0 & 1 \\
Sporophila lineola & 0 & 1 \\
Sporophila plumbea & 1 & 1 \\
Ammodramus humeralis & 0 & 0 \\
Emberezoides herbicola & 0 & 1 \\
Voltinia jacarina & 0 & 0 \\
Saltator atricollis & 1 & 1 \\
Anthus lutescens & 0 & 0 \\
Basileuterus culicivorus & 0 & 1 \\
Basileuterus leuconblepharus & 1 & 1 \\
Basileuterus flaveolus & 1 & 1 \\
Geothlypis aequinoctialis & 0 & 1 \\
Parula pitiayumi & 1 & 0 \\
Psarocollius decumanus & 1 & 0 \\
Chrysomus ruficapillus & 0 & 1 \\
Molothrus bonariensis & 0 & 0 \\
Gnorimopsar chopi & 0 & 0 \\
Euphonia chlorotica & 0 & 0 \\
Euphonia pectoralis & 1 & 0 \\
\hline & & \\
\hline
\end{tabular}

SNST - Species sensitivity to disturbance is described as a binary covariate: low sensitivity species (0) and medium sensitivity species (1).

STRAT - The foraging stratum was described as a binary covariate: not-understory birds (0) and understory-birds (1). Species that uses more than one stratum, including the understory, were categorized as (1). 


\section{Considerações finais}

Em áreas onde a maioria dos habitats naturais foram profundamente alterados pelo uso humano, a sobrevivência e a persistência a longo prazo de muitas espécies animais e vegetais pode depender principalmente do tipo de uso de solo e prática de manejo adotados na matriz. Dessa forma, para aumentar a eficácia dos esforços conservacionistas com enfoque na proteção da biodiversidade, é importante aumentar a qualidade dos diferentes tipos matriz agrícola. Para tanto é necessário investigar as relações entre riqueza de espécies e características da matriz, elucidar os processos e mecanismos ecológicos e evolutivos que determinam tais padrões de diversidade e entender como o uso de técnicas alternativas de manejo pode conciliar a conservação da biodiversidade e a produção agrícola.

Neste estudo demonstramos que plantações de Eucalyptus abrigam uma proporção pequena das espécies de aves presentes no pool regional. No entanto, também vimos que é possível incrementar o uso deste tipo de matriz pelas aves por meio da aplicação de determinadas técnicas de manejo durante a fase inicial do plantio, tais como a retenção de árvores nativas e o manejo mínimo de sub-bosque. Nossos resultados indicam que, mesmo dentro do intervalo de tempo de apenas um ciclo de plantio, algumas espécies de aves estão respondendo positivamente à pequenas variações na complexidade estrutural entre os talhões, e dentro do intervalo de tempo de apenas um ciclo de plantio. Assim, concluímos que gerenciadores interessados em aumentar a riqueza relativa de espécies de aves dentro da matriz de eucalipto devem buscar estratégias de manejo que manipulem os atributos estruturais dos talhões, de forma a maximizar a complexidade vertical e horizontal estrutural dentro e entre talhões.

Embora tenhamos encontrado evidências de que, na nossa escala de estudo, a quantidade de vegetação nativa no entorno do plantio tem uma influencia relativamente menor sobre a ocupação de aves do que as práticas de manejo adotadas dentro dos talhões, vimos que as espécies presentes na plantação de eucalipto são um mero subconjunto das espécies que ocorrem nos fragmentos de vegetação nativa. Esse fato sugere que os remanescentes de vegetação nativa desempenham o papel de fonte de espécies colonizadoras da matriz e que viabilizam a permanência de espécies que não conseguem se estabelecer nos eucaliptais. Nesse sentido, é provável que a conservação da diversidade regional de aves em área de silvicultura também seja 
influenciada pela heterogeneidade estrutural numa escala da paisagem, isto é, pela presença de remanescentes de vegetação nativa e outros tipos de cobertura do solo no entorno.

Por fim, vale a pena salientar que nesse estudo mensuramos o efeito de práticas de manejo e do contexto da paisagem sobre a diversidade de aves em plantios maduros. Considerando que importantes características estruturais das matrizes de silvicultura variam consideravelmente entre talhões recém-plantados e talhões maduros, é importante que estudos futuros investiguem a influencia da dimensão temporal sobre a dinâmica da comunidade de aves. Uma hipótese interessante a ser testada em estudos futuros é se o corte assincrônico dos talhões minimiza o impacto negativo da remoção de grandes porções de habitat sobre a riqueza de aves. 